\title{
The corrosion resistance of materials used for the manufacture of ear piercing studs
}

\author{
O.V. Correa*, M. Saiki*, S.O. Rogero* and I. Costa*
}

Abstract Nickel containing alloys have been widely used as substrates for the manufacture of studs used for ear piercing. Unfortunately, nickel has also been related to the development of allergic contact dermatitis caused by skin sensitization due to $\mathrm{Ni}^{2+}$ ions. Nickel ions can be leached out into the body fluids due to corrosion reactions. Defect free coatings are very difficult to produce, and therefore nickel free materials should be used as substrates of ear piercing studs, although the commercial alloys used usually contain this element. In this study, the corrosion resistance of two kinds of commercial studs prepared with nickel containing substrates and a titanium laboratory made stud was determined in a culture medium. The corrosion resistance of the studs was investigated by means of potentiodynamic polarization tests and electrochemical impedance spectroscopy as a function of immersion time in the culture medium. The elements that leached out into the medium due to corrosion reactions were analyzed by instrumental neutron activation analysis. The surfaces of the commercial gold-coated studs were examined by scanning electron microscopy and analyzed by energy dispersive spectroscopy, both before and after exposure to the culture medium. The cytotoxicity of the tested studs was also determined in the culture medium.

Keywords Corrosion. Gold coated studs. Electrochemical impedance spectroscopy. Titanium. Nickel.

\section{Resistencia a la corrosión de materiales utilizados para la fabricación de aretes perforantes para orejas}

Resumen Aleaciones conteniendo níquel se han utilizado como substratos para la fabricación de aretes perforantes para orejas. Desafortunadamente, el níquel ha sido relacionado con el desarrollo de una reacción alérgica conocida como dermatitis de contacto, causada por la sensibilización debido a los iones de $\mathrm{Ni}^{2+}$. Estos iones pueden ser liberados hacia los fluidos corporales debido a las reacciones de corrosión. Los aretes, habitualmente, se revisten con películas de oro. Sin embargo, es muy difícil hacer los revestimientos libres de defectos superficiales. Por lo tanto, materiales sin níquel deberían utilizarse como substratos en aretes perforantes para orejas, aunque las aleaciones comercialmente utilizadas presentan níquel en su composición. En este estudio, la resistencia a la corrosión de dos tipos de aretes comerciales fabricados con substrato conteniendo níquel y de un arete de $\mathrm{Ti}$, preparado en laboratorio, se determinó en un medio de cultivo. La resistencia a la corrosión de los aretes se investigó por medio de ensayos de polarización potenciodinámica y espectroscopia de impedancia electroquímica, en función del tiempo de inmersión en el medio de cultivo. Los elementos liberados en el medio debido a las reacciones de corrosión se analizaron por la técnica instrumental de activación con neutrones. Las superficies de los aretes comerciales revestidos con oro se examinaron por microscopía electrónica de barrido y se analizaron por espectroscopia de energía dispersiva, antes y después de la exposición al medio de cultivo. La citotoxicidad de los aretes probados se determinó, también, en el medio de cultivo.

Palabras clave Corrosión. Aretes con revestimiento de oro. Espectroscopía de impedancia electroquímica. Titanio. Níquel.

$\left(^{*}\right)$ Instituto de Pesquisas Energéticas e Nucleares-IPEN/CNEN-SP. Centro de Ciência e Tecnologia de Materiais. Caixa Postal 11049, Cidade Universitaria. CEP 05422-970. São Paulo-SP. Brazil.

Rev. Metal. Madrid Vol. Extr. (2003) 91.96 
The corrosion resistance of materials used for the manufacture of ear piercing studs

O.V. Correa, M. SaIKI, S.O. Rogero and I. Costa

\section{INTRODUCTION}

Alloys containing nickel in their composition are generally used in the manufacture of ear piercing studs. On these studs surfaces gold coatings are applied for aesthetic reasonn, corrosion resistance and because gold has been generally accepted as having little or no cytotoxicity ${ }^{[1]}$. These coatings should be compact and adherent to the substrate, to avoid the contact between substrate elements and body fluids while the pierced earlobes are healing. However, in the coating process defects are usually introduced, and that allows the corrosion of the substrate and the release of nickel ions. Nickel is the major cause of allergic contact dermatitis ${ }^{[2-7]}$, this being caused by $\mathrm{Ni}^{2+}$ ions, which bind to tissue and intersticial fluid proteins as soon as they are released from the metallic substrate ${ }^{[3]}$.

In a previous study, neutron activation analysis was applied to determine the elements leached out due to corrosion of two alloys used for producing ear piercing studs ${ }^{[8]}$. In the present work, the corrosion resistance of two commercial gold coated ear piercing studs, with a copper-zinc based alloy and a stainless steel as substrates, and a laboratory made $\mathrm{Ti}$ stud, have been investigated by electrochemical impedance spectroscopy and potentiodynamica polarization tests.

The purpose of this investigation was to contribute in the study of alloys that are being used in the fabrication of ear piercing studs and that are being associated to allergic reactions. Besides, a laboratory made $\mathrm{Ti}$ stud was tested as a potential material for substitution of the alloys currently used.

\section{MATERIALS AND METHODS}

\subsection{Materials}

Three types of ear piercing studs have been studied: gold coated austenitic stainless steel $(\mathrm{St})$; gold coated copper-zinc alloy (Pf) and titanium (Ti). Figure 1 illustrates one of the tested studs.

The compositions of the materials used as substrates were determined by instrumental neutron activation analysis (INAA) and the results are given in table I. In these analyses, the stems and butterfly backs of studs were analysed individually after removing the gold coating.

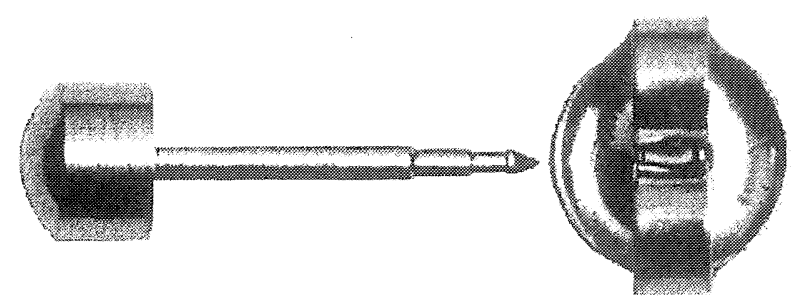

Figure 1. Photograph of one of the tested studs.

Figura 1. Fotografía de uno de los aretes probados.

Table I. Elemental composition of ear piercing studs obtained by instrumental neutron activation analysis

Tabla I. Composición elemental de los aretes perforantes obtenida por análisis instrumental por activación con neutrones

\begin{tabular}{lccc}
\hline Element & $\begin{array}{c}\text { Substrate of } \\
\text { Pf studs }\end{array}$ & $\begin{array}{c}\text { Substrate of } \\
\text { St studs }\end{array}$ & $\begin{array}{c}\text { Ti ear piercing } \\
\text { studs }\end{array}$ \\
\hline${\text { As } \mu g^{-1}}^{-1}$ & $8.1 \pm 0.5$ & $57.4 \pm 0.8$ & $17.7 \pm 0.3$ \\
${\text { Co } \mu g^{-1}}^{2}$ & $27.4 \pm 0.4$ & $2203 \pm 11$ & $\leq 1$ \\
$\mathrm{Cr} \%$ & $0.0070 \pm 0.0005$ & $16.1 \pm 0.2$ & $0.0096 \pm 0.0001$ \\
$\mathrm{Cu} \%$ & $36.5 \pm 1.2$ & $0.35 \pm 0.01$ & $\leq 0.04$ \\
$\mathrm{Fe} \%$ & $9.0 \pm 0.2$ & $67.9 \pm 0.2$ & $\leq 0.04$ \\
$\mathrm{Mn} \%$ & $2.34 \pm 0.07$ & $1.81 \pm 0.02$ & $0.0007 \pm 0.0002$ \\
$\mathrm{Mo} \%$ & $\leq 0.2^{*}$ & $0.394 \pm 0.002$ & $\leq 0.0003$ \\
$\mathrm{Ni} \%$ & $6.80 \pm 0.07$ & $7.86 \pm 0.07$ & $0.009 \pm 0.001$ \\
$\mathrm{Ti} \%$ & $\leq 23$ & $\leq 23$ & $97.4 \pm 6.4$ \\
$\mathrm{~V} \mu \mathrm{g} \mathrm{g}{ }^{-1}$ & $\leq 77$ & $987 \pm 26$ & $33 \pm 3$ \\
$\mathrm{Zn} \%$ & $36.4 \pm 3.3$ & $\leq 0.7$ & $\leq 0.002$ \\
\hline
\end{tabular}

* For the elements not detected, the detection limit values were evaluated according to Currie[1968].

\subsection{Corrosion tests}

The corrosion performance of the three types of studs was investigated by means of Electrochemical Impedance Spectroscopy (EIS) and potentiodynamic polarization tests. The perturbation amplitude of voltage for the EIS test was $10 \mathrm{mV}$ and the frequency range was from 50 $\mathrm{kHz}$ to $5 \mathrm{mHz}$. These measurements were carried out in a MEM culture medium at room temperature, at the open circuit potential. A threeelectrode cell arrangement was used for the electrochemical tests, with a graphite rod as the auxiliary electrode, a saturated calomel electrode (SCE) as the reference electrode and cold resin mounted studs as the working electrode. The studs were mounted in an epoxy resin leaving only their stem for exposure to the culture medium. 
The specimens were immersed in the culture medium for various times (from one to nine days) and the EIS test was carried out as a function of time. Polarization tests were carried out on the Pf and St studs, after removal of their gold coatings with $\mathrm{Hg}$, from the corrosion potential $\left(\mathrm{E}_{\mathrm{corr}}\right)$ up to $+1300 \mathrm{mV}(\mathrm{SCE})$ after 5 days of immersion. The coating was removed to avoid localized corrosion in the defects of the coating, and to allow a comparison of the corrosion resistances of the substrates of the materials tested.

\subsection{Chemical analysis}

Twelve pair of studs were immersed in the MEM culture medium for $10 \mathrm{~d}$ After this period the studs were removed and the medium was analysed by applying instrumental neutron activation analysis (INAA), according to procedure described in a previous paper ${ }^{[8]} .500 \mu \mathrm{L}$ of each extract solution was pipetted and dried in a clean polyethylene capsule for irradiation in the IEA-R1 nuclear reactor. The gamma ray spectra obtained were processed using appropriate software and the concentrations of the elements were calculated by a comparative method. Also, the blank of the culture medium was analysed to evaluate the elements from this medium.

\subsection{Cytotoxicity test}

The cytotoxicity assay was carried out according to Rogero et al. ${ }^{[9]}$ and the International Standards Organization $(\mathrm{ISO})^{[10]}$ by adding diluted culture medium after immersion of studs in contact with Chinese Hamster Ovary cells culture (ATCC $\mathrm{CHO}$ k1) The determination of cytotoxicity, according to ISO, can be either qualitative or quantitative. In this study, the determination of cytotoxicity was performed by quantitative evaluation, based on cell viability.

\subsection{Scanning electron microscopy (SEM) and energy dispersive spectroscopy (EDS)}

The surface characteristics of the studs were examined in a Scanning Electron Microscope (SEM) and analysed by Energy Dispersive Spectroscopy (EDS), before and after ten days immersion in the culture medium. The aim of these analyses was to examine the coatings for defects, which could expose the substrate, and for the presence of reaction products on the surface.

\section{RESULTS}

\subsection{Polarization tests}

The results of polarization tests after 5 days of immersion are shown in figure 2. The largest corrosion current densities among the materials tested were related to Pf substrate. It also showed a pitting potential at around $500 \mathrm{mV}$ (SCE). Low corrosion current densities were obtained for the $\mathrm{St}$ substrate up to high overpotentials, and only a slight increase was seen at approximately $850 \mathrm{mV}$ (SCE). Ti stud showed a behaviour typical of an active corrosion reaction (anodic Tafel behaviour), in a large range of overpotentials, (approximately $550 \mathrm{mV}$ ). However, the very low current densities (order of $\mu \mathrm{A} . \mathrm{cm}^{-2}$ ) up to the oxygen evolution reaction potential, indicated that it was passive.

\subsection{EIS tests}

The EIS results after 1 day of immersion showed large differences in the corrosion response of the three studs tested (Fig. 3). Only one time relaxation constant was associated to the St stud, whereas two time relaxation constants were related to the $\mathrm{Ti}$ and Pf studs. The St stud showed a capacitive behaviour in a large frequency range (from $10^{3}$ to $10^{-2} \mathrm{~Hz}$ ) suggesting a good quality of the gold coating on this stud.

Increasing the time of immersion only caused very slight changes on the EIS response of the coated St stud (Fig. 4) supporting the good characteristics of the coating. It is important to keep in mind that the substrate of this coating

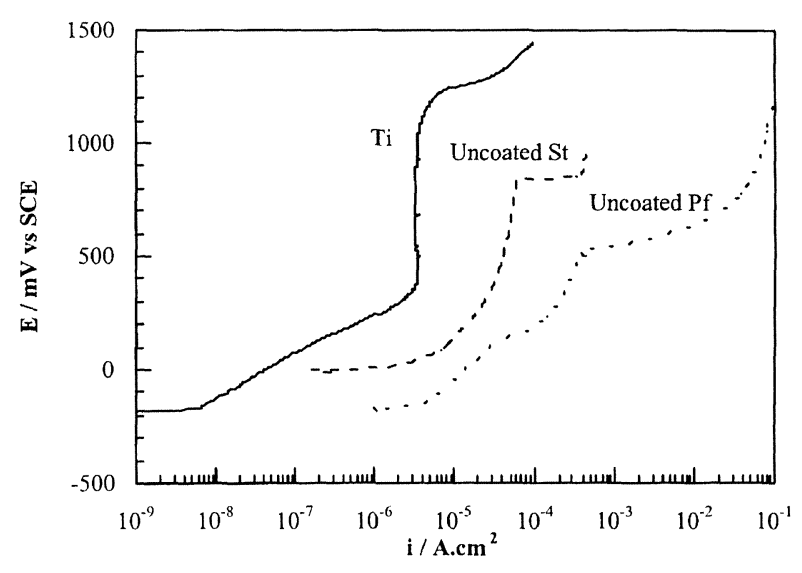

Figure 2. Polarization curves of substrates of studs after $5 d$ in culture medium.

Figura 2. Curvas de polarización de los substratos de los aretes después de $5 \mathrm{~d}$ en el medio de cultivo. 


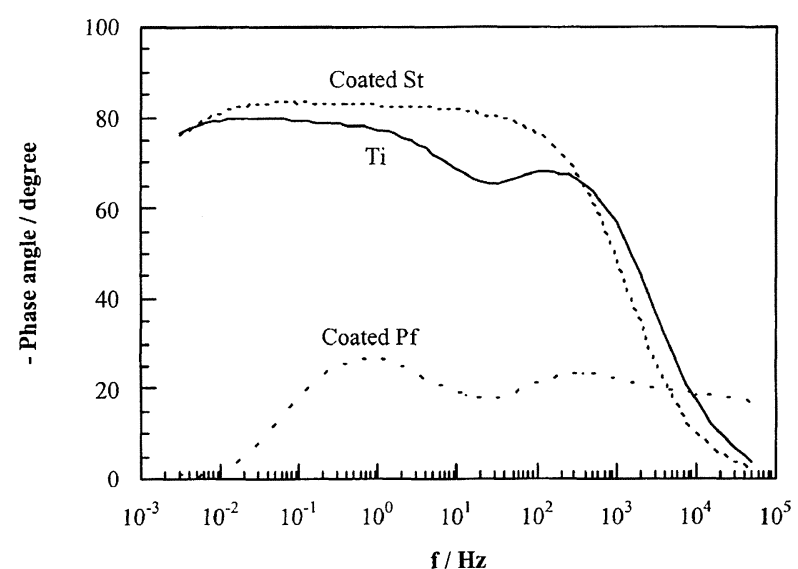

Figure 3. Bode phase angle plots of the tested studs after 1 $\mathrm{d}$ of immersion in culture medium.

Figura 3. Espectros de Bode (ángulo de fase) de los aretes probados, después de $1 d$ de inmersión en el medio de cultivo.

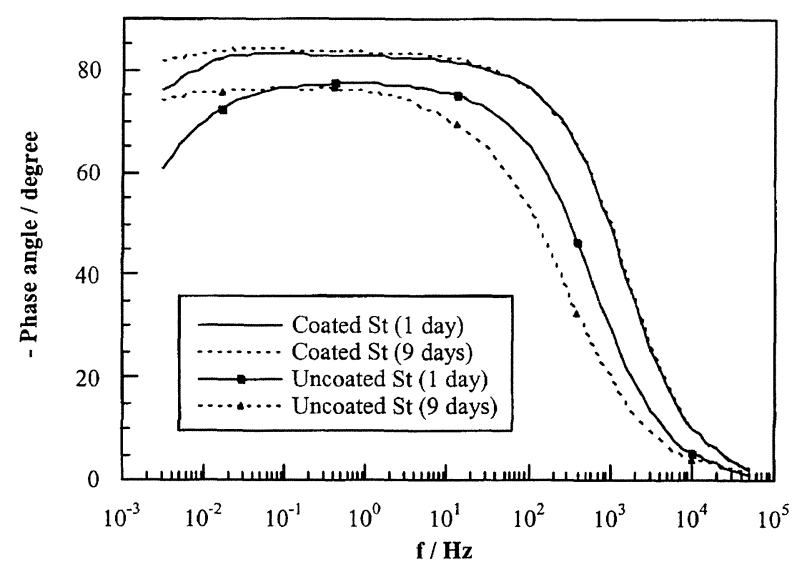

Figure 4. Bode plots of coated and uncoated St stud after 1 and $9 \mathrm{~d}$ in culture medium.

Figura 4. Espectros de Bode del arete St con y sin revestimiento, después de 1 y 9 d de inmersión en el medio de cultivo.

(austenitic stainless steel) also showed a high corrosion resistance in the culture medium, as indicated by the polarization tests. For the uncoated St stud, the increase in immersion time caused an increase of the double layer capacitance. A capacitive behaviour was also indicated by the EIS results obtained for the uncoated St stud at low frequencies.

The effect of increasing immersion time of $\mathrm{Ti}$ studs, occurred mainly in the relaxation process at the high frequencies (Fig. 5). This was likely due to the oxide on $\mathrm{Ti}$ stud surface. From one to three days of immersion, EIS results suggested a decrease in the resistance of this oxide, possibly due to an

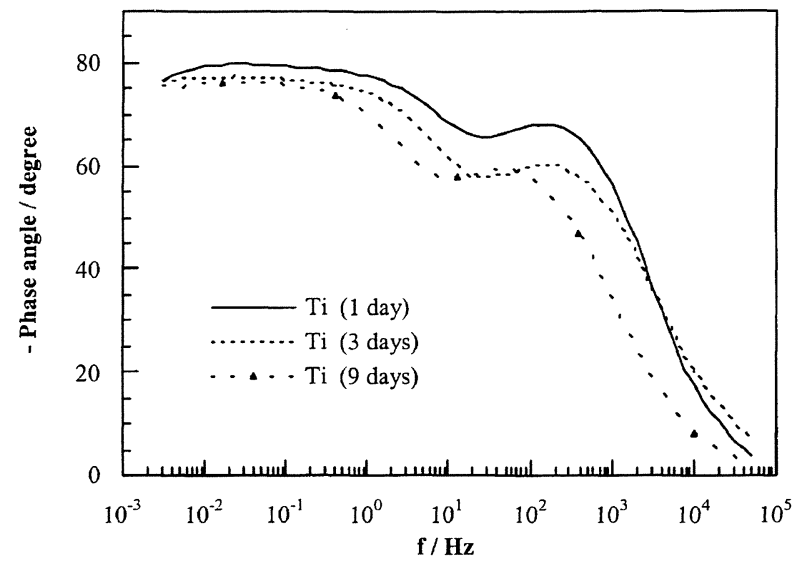

Figure 5. Bode plots of Ti studs at increasing immersion time.

Figura 5. Espectros de Bode de aretes de Ti en tiempos crecientes de inmersión.

increase in its porosity, and from three to nine days, an increase in its capacitance was indicated. The observation of a relaxation process at the low frequency range suggests that this oxide was porous, and the electrolyte reached the metallic substrate at the pores base. A capacitive behavior was seen at low frequencies during the whole test period, indicating a high corrosion resistance of the Ti stud in the culture medium.

Significant changes occurred in the EIS results of the Pf stud with increasing immersion time, at high and low frequencies (Fig. 6-a). The high frequency relaxation process was likely related to the coating and the low frequency response to the corrosion process of the substrate at the base of defects in the coating.

From two to three days of immersion, the peak at low frequencies was broadened, indicating the interaction of two time constants. These two time constants were separated after nine days of immersion.

The relaxation process at frequencies from $10^{2} \mathrm{~Hz}$ to $10^{-1} \mathrm{~Hz}$, was possibly due to the precipitation of corrosion products in the defects of the coating. The thickening of these products, leading to an increase in its resistance, associated to a decrease in the charge transfer resistance, might have caused the separation of the two time constants from three to nine days of test. A diffusion controlled process through this layer was also indicated in the EIS results. The response relative to the interface metallic material/electrolyte, seen at low frequencies, after corrosion products have been formed in the defects, suggests that these products were porous allowing the penetration of the 
electrolyte into the metallic substrate. These results indicate that Pf stud was continuously corroding during the whole test period, even after corrosion products have been deposited in the defects.

Nyquist plots of Pf stud immersed in the culture medium at times corresponding to one to three days, showed depressed semicircles at high frequencies (Fig. 6-b). This indicated the interaction of various time constants, possibly due to the heterogeneities in the coating, such as defects.

\subsection{Scanning electron microscopy (SEM) and energy dispersive spectroscopy (EDS)}

Defects were observed in the coating of Pf studs before immersion in the culture medium, (Fig. 7a). After few days of immersion, corrosion products were seen on the Pf surface, associated to defects of the coating (Fig. 7-b). This product was presumably zinc phosphate, as indicated by EDS
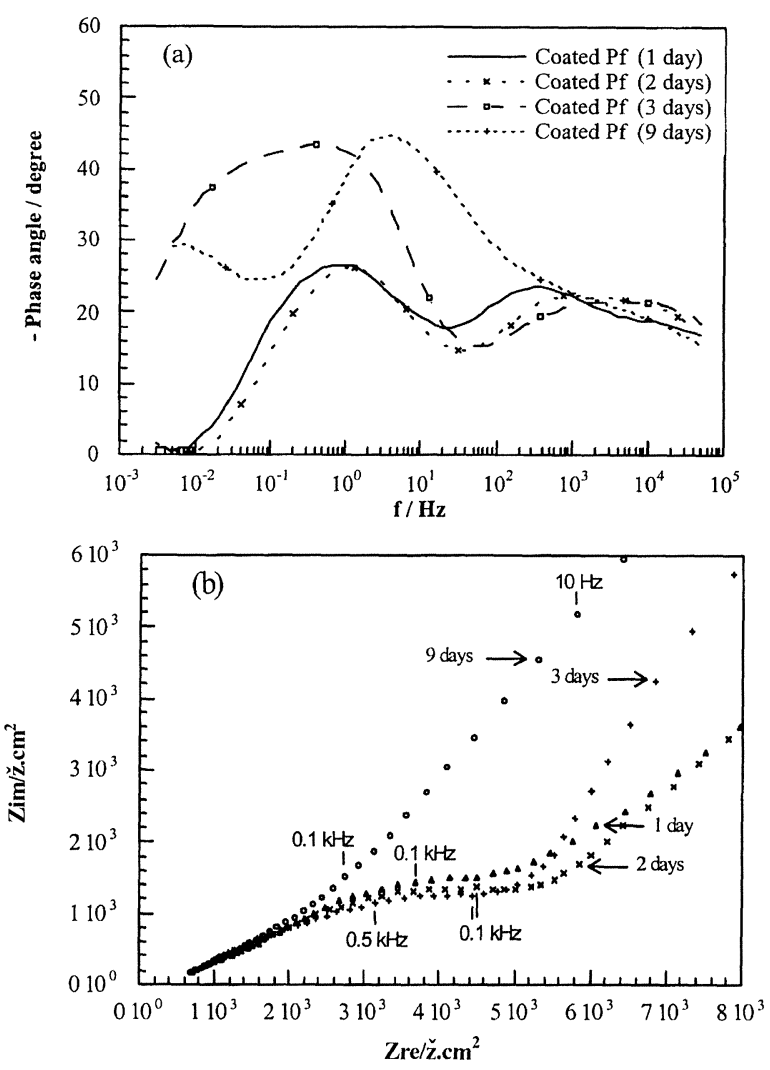

Figure 6. a) Bode plots and b) Nyquist plots of coated Pf studs at increasing immersion times.

Figura 6. (a) Espectros de Bode y (b) diagramas de Nyquist de aretes Pf con revestimiento en tiempos crecientes de inmersión.

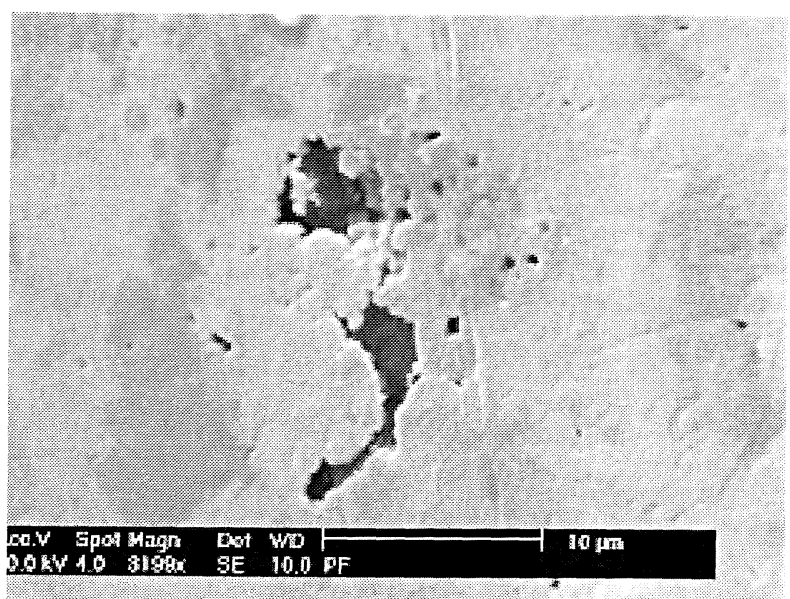

a)

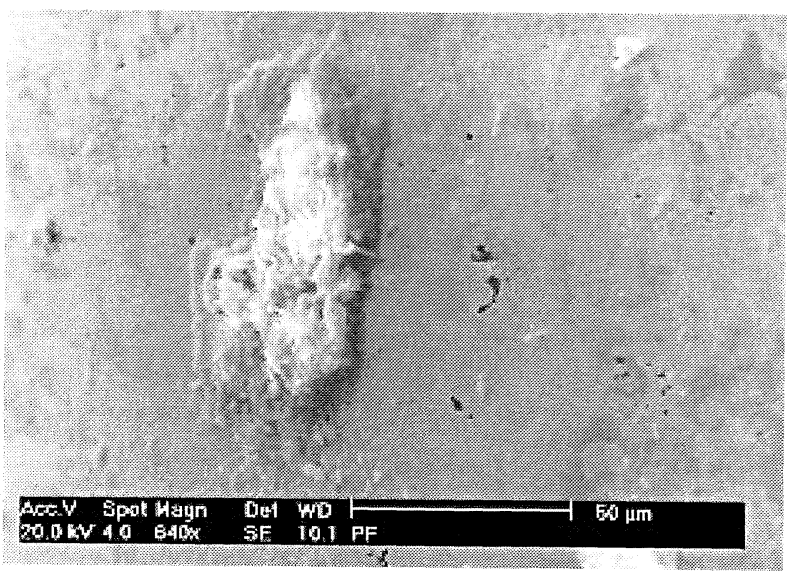

b)

Figure 7. MEV of a stud surface before and after corrosion test. a) Defects in the coating on Pf stud before corrosion test, b) corrosion products deposited on a defect in the coating during corrosion test.

Figura 7. Microscopía electrónica de barrido de la superficie de un arete, antes y después del ensayo de corrosión: (a) Defectos en el revestimiento sobre el arete Pf antes del ensayo de corrosión, (b) productos de corrosión depositados en el defecto del revestimiento durante el ensayo de corrosión.

analysis (Fig. 8). It is important to mention that phosphate is a component of the culture medium.

\subsection{Chemical analysis of the culture medium after corrosion}

The results of element determination in the culture medium after ten days of studs exposure, and in the blank solution composed of the same culture medium, are presented in table II. Results obtained for $\mathrm{Ni}$ indicated that this metal was released from both gold-coated studs tested. This shows that despite the good characteristics of the gold coating on St stud, $\mathrm{Ni}$ is released into the corrosive medium and this can lead to allergic 


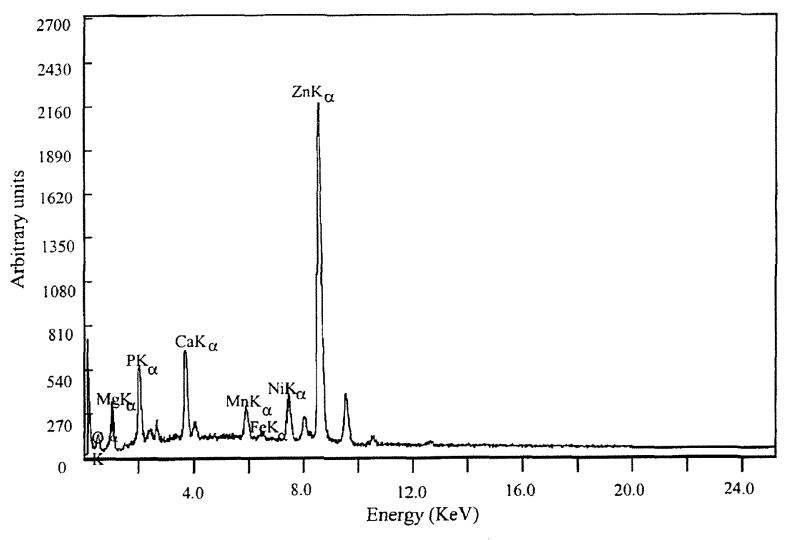

Figure 8. EDS of corroded area.

Figura 8. Análisis de energía dispersiva en la área corroída.

Table II Elemental concentrations in the culture media and in the blank

Tabla II. Concentraciones de los elementos en el medio de cultivo y en el blanco

\begin{tabular}{lcccc}
\hline & & \multicolumn{4}{c}{$\begin{array}{c}\text { Culture medium after } 10 \mathrm{~d} \\
\text { of studs immersion }\end{array}$} \\
\cline { 3 - 5 } Element & Blank & Pf & St & Ti \\
\hline Co $\mathrm{ng} / \mathrm{mL}$ & $12.1 \pm 1.2$ & $61.6 \pm 0.5$ & $99 \pm 10$ & $53.8 \pm 2.1$ \\
$\mathrm{Cr} \mu \mathrm{g} / \mathrm{mL}$ & $0.72 \pm 0.02$ & $0.73 \pm 0.04$ & $0.73 \pm 0.03$ & $0.75 \pm 0.03$ \\
$\mathrm{Fe} \mu \mathrm{g} / \mathrm{mL}$ & $0.60 \pm 0.09$ & $0.61 \pm 0.08$ & $4.03 \pm 0.31$ & $0.43 \pm 0.11$ \\
$\mathrm{Ni} \mu \mathrm{g} / \mathrm{mL}$ & N.D.* & $0.96 \pm 0.09$ & $0.66 \pm 0.06$ & N.D. \\
Zn $\mu \mathrm{gmL}$ & $0.58 \pm 0.05$ & $3.84 \pm 0.41$ & $0.61 \pm 0.01$ & $0.75 \pm 0.10$
\end{tabular}

N.D.* - Not detected

reaction. The culture medium where the stem substrate of Pf studs were immersed presented a high concentration and $\mathrm{Zn}$ and that where the St studs were exposed, high levels of Fe were detected. The high zinc content in the culture medium after ten days of studs immersion (six times that of the blank) shows that this element was leached from the alloy used as substrate, due to significant corrosion, supporting the EIS results. In the extract from $\mathrm{Ti}$ studs, the elements detected were of the same order of magnitude as that in the blanks, indicating their passivity in the culture medium.

\subsection{Cytotoxicity test}

The cytotoxic potential can be quantitatively expressed as cytotoxicity index $\left(\mathrm{IC}_{50(\%)}\right)$. The cytotoxicity index is the concentration of the extract necessary to suppress colony formation to $50 \%$ of the control value. St and Pf commercial studs showed cytotoxicity, presenting $\mathrm{IC}_{50}(\%)=78$ and 44 , respectively, Pf with higher toxicity. On the other hand, Ti studs was not cytotoxic, $\mathrm{IC}_{50(\%)}>100$.

\section{CONCLUSIONS}

The results showed that the studs investigated had large differences in their corrosion resistance. The stud associated to the highest corrosion resistance was St. This was partially attribute to the good characteristis of the gold coating on this stud and partially to the high corrosion resistance of its substrate (stainless steel). However, nickel was leached from St stud substrate into the culture medium and it was cytotoxic. Pf stud, on the other hand, was related to the lowest corrosion resistance, higher concentration of $\mathrm{Ni}$ released due to corrosion and higher cytotoxicity. Ti stud showed the best combination of properties, specifically high corrosion resistance, absence of $\mathrm{Ni}$ in its composition and absence of cytotoxicity. The results pointed out to the importance of using $\mathrm{Ni}$ free materials for the manufacture of ear piercing studs.

\section{Acknowledgements}

The authors are thankful to FAPESP for the financial support provided to this work.

\section{REFERENCES}

[1] J.C. Wataha, R.G. Craig and C.T. Hanks, J.Dent.Res. 70 (1991) 1.014-1.018.

[2] R. BReits TA D T, Galvanotechnik 83 (1992) 1691-1695.

[3] J. Rynänen, E. Niem l, W. Serlo et al., J. Biomed. Mater.Res. 35 (1997) 451-457.

[4] Y. Ikarashi, J. Momma, T. Tsuchiya and A. NA K A M UR A, Biomaterials 17 (1996) 2103-2108.

[5] J. YA N G and K. MerRit, J. Biomed. Mater. Res. 28 (1994) 1249-1258.

[6] K. Bordji, J.Y. Jouzeau, D. Mainard, E. Payan, J.P. Delagoutte and P. Ne t T E R, Biomaterials 17 (1996) 491 495.

[7] C. Meijer, M. Bredierg, T. Fischer and L. VI D S R Ö, Contact Dermatitis 32 (1995) 147-149.

[8] M. Saiki, S.O. Rogero, I. Costa, O.V. Correa and O.Z. Higa, Radiat. Phys. Chem. 55 (1999) 753-756.

[9] S.O. Rogero, F.J.C. Braga and O.Z. Higa, Mater.Sci.Forum 299-300 (1999) 44-47.

[10] ISO document 10993, 1992. 